Attadrib: Jurnal Pendidikan Guru Madrasah Ibtidaiyah

(p-ISSN: 2599-3194 | e-ISSN: 2775-8109

Volume 4, Issue. 01, 2021, pp. 62-71

\title{
Pembelajaran Pendidikan Agama Islam Kontekstual di Sekolah Dasar Alam
}

\author{
Tri Era Khoiriyah ${ }^{1}$, Hakiman $^{2}$, Aminudin $^{3}$ \\ ${ }^{1}$ Fakultas Ilmu Tarbiyah, Universitas Islam Negeri Raden Mas Said Surakarta, Indonesia \\ ${ }^{2}$ Fakultas Ilmu Tarbiyah, Universitas Islam Negeri Raden Mas Said Surakarta \\ ${ }^{3}$ Fakultas Ilmu Tarbiyah, Universitas Islam Negeri Raden Mas Said Surakarta \\ erachoiriyah30@gmail.com, hakiman.iman@gmail.com, e nudie@yahoo.co.id.
}

Submitted: 25-08-2021 Revised : 10-10-2021 Accepted: 30-10-2021

\begin{abstract}
This article attempts to examine the implementation of Islamic Education Through Contextual Learning on Bengawan Solo Alam Elementary School, Klaten. Teacher as educator should present am Islamic Education learning which is packeaged attractively so that students not only understand the learning cognitively but also have behavioral enlightenment and apply it in daily life. The research is field research, that is research field where researchers present directly in the research. Data collection techniques used is observation, interview, documentation and Group Discussion. Data validation techniques used are triangulation technique, sources, and methods. Data analysis techniques start on the reduction of the data, presentation of data and the draw the conclusions. The result of this article showed that the implementation of Islamic Education contextual learning in Bengawan Solo Alam Elementary School through: 1) integration to all subjects, 2) take advantage of nature 3) prioritizing practice and experience, 4) exemplary and habituation, 5) associate with local culture. Learning activities supported by: gardening, outing class, dhuba prayer before learning, congregational prayer at the village mosque, and social activities.
\end{abstract}

Keywords: Islamic Learning, Islamic Education, Contextual Learning, Elementary School

Https://doi.org/10.54069/attadrib.v4i2.147

How to Cite Khoiriyah, T.E Hakiman. Aminuddin. (2021). Pembelajaran Pendidikan Agama Islam Kontekstual di Sekolah Dasar Alam. Attadrib: Jurnal Pendidikan Guru Madrasab Ibtidaiyah, Volume $4(2), 62-71$

\section{PENDAHULUAN}

Pendidikan Agama Islam merupakan bagian dari mata pelajaran yang tidak ketinggalan ketika di sekolah umum, mata pelajaran ini diperoleh sejak berada sekolah dasar bahkan hingga perguruan tinggi. Sistem pendidikan yang ada di Indonesia biasanya memberikan Pendidikan Agama Islam pada peserta didik yang khusus beragama Islam. Pembelajaran Pendidikan Agama Islam mempunyai tujuan utama yaitu bagaimana nilai-nilai ajaran Islam yang diajarkan mampu tertanam di dalam diri peserta didik, sehingga dapat merubah tingkah laku sesuai dengan nilainilai ajaran Islam baik dalam kehidupan pribadi maupun sosial. Hal tersebut biasanya disebut dengan istilah terbentuknya "insan kamil". Terlebih Pendidikan Agama Islam pada tingkat SD yang berada kisaran usia 7 sampai 12 tahun. Menurut Suarjana (2015) pada usia 7 sampai 12 tahun anak-anak sedang berada pada tingkat berfikir operasi konkrit, anak akan mengembangkan konsep dengan cara menggunakan benda-benda kokrit untuk menyelidiki adanya hubungan dan ide yang bersifat abstrak.

Idealitasnya Pendidikan Agama Islam memuat tiga aspek secara terpadu, yaitu: knowing, yaitu peserta didik dapat mengetahui dan memahami ajaran dan nilai-nilai agama; doing, yakni agar 
peserta didik dapat mempraktikkan ajaran dan nilai-nilai agama; dan being, yakni agar peserta didik dapat menjalani hidup sesuai dengan ajaran dan nilai-nilai agama (Muhaimin, 2002). Dalam prakteknya pembelajaran Pendidikan Agama Islam terdapat banyak rintangan dan juga kendala. Menurut Ilyas et al., (2018) pembelajaran Pendidikan Agama Islam yang ada di SDN Kecamatan Lima Kaum Batusangkar masih dominan bersifat kognitif menekankan pada transfer ilmu, menggunakan metode pembelajaran yang cenderung konvensional atau tradisional misalnya menggunakan metode ceramah yang berfokus pada guru saja. Hal tersebut mengakibatkan peserta didik menjadi pasif, pengetahuan agama hanya terfokus pada kognitif, kurang bisa mengubah menjadi nilai yang bermakna dalam kehidupan. Dalam penelitian Muslimin (2017) bahwa problematika yang dialami oleh guru PAI berkaitan dengan profesionalismenya. Problem tersebut meliputi: perumusan tujuan pembelajaran, metode yang tidak tepat dan cenderung kurang kreatif menggunakan metode yang monoton, perumusan materi pembelajaran serta penguasaannya, pemanfaatan media pembelajaran yang kurang sesuai dengan isi dari materi pelajaran yang diajarkan, dan pelaksanaan kegiatan evaluasi yang belum maksimal.

Menurut Rouf (2015) kurang maksimalnya pendidikan agama Islam di sekolah dipengaruhi beberapa faktor yaitu: 1) Kurangnya kompetensi guru sebagai tenaga yang profesional dan dedikasinya sesuai dengan tuntutan pendidikan. 2) Hubungan pendidik dengan murid yang bersifat formal, tidak berkelanjutan menjadi informal saat di luar kelas. 3) Guru nyaman menggunakan metode pembelajaran tradisional dari pada metode kontekstual, sehingga kurang mampu menarik minat peserta didik. Dari berbagai permasalahan di atas menunjukkan kurangnya kompetensi guru dalam mengajar sehingga pembelajaran hanya terfokus pada guru dan kurang melibatkan peserta didik. Artinya guru tersebut nyaman menggunakan konsep pengajaran konvesional (tradisional). Penyampaian pembelajaran hanya dilakukan pada lingkup kelas saja, ketika berada di luar kelas Pendidikan Agama Islam tidak disampaikan. Pendidikan Agama Islam masih dipandang sebagai mata pelajaran yang dipelajari secara teoritis saja dan kurang menekankan pada aspek sikap dan prakteknya.

Pembelajaran hendaknya memaksimalkan dari ketiga potensi yang dimiliki manusia yaitu potensi pendengaran, potensi penglihatan, dan potensi hati. Seperti pada QS. An-Nahl: 78 yang Artinya: "Dan Allah mengeluarkan kamu dari perut ibumu dalam keadaan tidak mengetahui sesuatupun, dan dia memberi kamu pendengaran, penglihatan, dan hati agar kamu bersyukur."(Depag 2012)

Dijelaskan bahwa dalam kegiatan pembelajaran untuk melibatkan peran aktif peserta didik, tidak hanya proses melibatkan fisiknya saja (yaitu pendengaran dan penglihatan), tetapi juga melibatkan psikisnya (yaitu hati) (Hartono, 2013). Selaras dengan ayat tersebut siswa pada tingkat SD memerlukan pembelajaran yang konkrit, dalam pembelajaran siswa harus disediakan benda atau peristiwa yang nyata. Hal tersebut perlu dilakukan supaya siswa mudah dalam menerima apa yang diajarkan oleh gurunya, sehingga diperlukan pembelajaran yang kontekstual yang dekat dengan situasi dan kondisi anak. Inovasi dapat dilakukan dengan menghadirkan pembelajaran berbasis kontekstual yang dapat membantu peserta didik untuk mengaitkan pengetahuan yang sudah dimiliki dengan kedaan lingkungan, baik lingkungan sekolah, keluarga, dan masyarakat.

Menurut Tamam (2015) dalam penelitiannya mengungkapkan bahwa pembelajaran kontekstual dilakukan dengan menghadirkan suasana pembelajaran kondusif, penilaian dilakukan menyeluruh meliputi ranah kognitif, afektif dan psikomotor. Motivasi belajar dan keterlibatan dalam mengikuti pembelajaran menunjukkan cukup aktif dan hasil belajar diatas rata-rata nilai KKM, serta mimiliki sikap sosial maupun spiritual. Pada penelitian tersebut belum disampaikan terkait bagaimana kegiatan pembelajaran PAI. Sedangkan dalam penelitian Choir (2019) bahwa pembelajaran PAI menggunakan aktivitas kontekstual dengan mendekatkan peserta didik pada kehidupan nyata, sehingga pembelajaran PAI menjadi aplikatif dan implementatif sesuai dengan tuntutan kehidupan. Artikel menggali dan menemukan bagaimana pembelajaran kontektual. 


\section{METODE}

Metode penelitian ini adalah kulaitatif deskriptif yang objek penelitiannya di Sekolah Dasar Alam Bengawan Solo. Pengumpulan datanya melalui wawancara, observasi, dokumentasi dan forum diskusi. Untuk menguji kevalidan data peneliti menggunakan triangulasi sumber dan metode. Adapun teknik análisis datanya menggunakan teknik análisis interaktif Miles Huberman.

\section{HASIL PENELITIAN DAN PEMBAHASAN}

\section{Hasil Penelitian}

Pembelajaran kontektual di Sekolah Dasar Alam Bengawan Solo dilakukan dengan tujuan untuk membantu siswa memahami modul akademik yang mereka pelajari dengan menghubungkan tema akademik dengan lingkungan dalam kehidupan sehari-hari. Pembelajaran melibatkan berbagai aspek yaitu kognitif, afektif dan psikomotorik. Pembelajaran kontektual dihadirkan dalam rangka memberikan pendidikan agama Islam yang koheren dan komprehenshif. Pembelajaran kontektual perlu nampak didalam kurikulum dan pelaksanaan pembelajaran dan manajemen pembelajaran. Pembelajaran kontektual di Sekolah Alam bengawan Solo dalam implementasinya dapat dilihat dari adanya integrasi PAI dalam semua mata Pelajaran, memanfaatkan alam, melalui keteladanan dan pembiasaan dan mengaitkan pembelajaran dengan budaya lokal.

\section{Integrasi PAI dalam Semua Mata Pelajaran}

Berdasarkan analisis spider web dan detail activity semester genap, bahwa dua instilah tersebut di gunakan sebagai pengganti perangkat pembelajaran seperti Silabus dan RPP. Diketahui bahwa silabus yang di berikan disusun dalam bentuk tema dengan model spider web. Tema tersebut terintegrasi dari seluruh mata pembelajaran yang ada di Sekolah Alam, dengan adanya integrasi keterkaitan melalui tema dapat membantu dalam memahami dan mengaitkan materi belajar dengan situasi kontekstual. Gambaran dari spider web sebagai berikut:

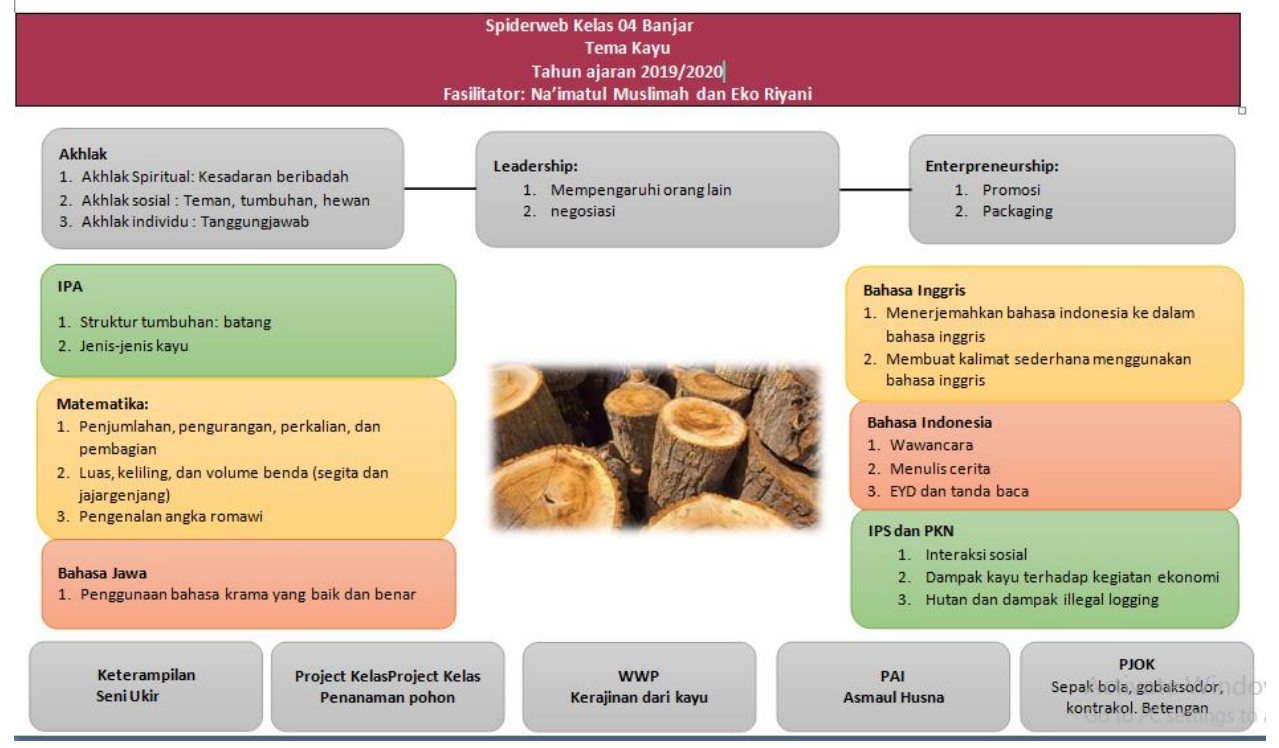

Gambar 1. spider web Kelas IV tema kayu

Terlihat bahwa tema yang di angkat pada spider web semester genap adalah kayu dengan sub materi PAI mengenai Asmaul Husna selain itu terdapat materi akhlak spiritual, akhlak individu, akhlak sosial. Materi PAI dan akhlak kemudian di integrasikan dengan mata pelajaran lain diantaranya Bahasa Jawa, IPA, Matematika, PKN, IPS, Bahasa Inggris, Bahasa Indonesia, dan mata pelajaran lain.

Asmaul Husna dimunculkan supaya peserta didik dapat mengkorelasikan dan mengimplementasikan materi dengan peristiwa sehari-hari dengan sifat-sifat Allah (Asmaul 
Husna). Mengintegrasikan materi PAI ke dalam ilmu umum tidak hanya memungkinkan peserta didik mempelajari ilmu agama, tetapi juga memahami hubungannya dengan ilmu umum. Penerapan pembelajaran Pendidikan agama Islam kontekstual di Sekolah Dasar Alam Bungawan Solo Klaten secara spesifik dapat dilihat dari kegiatan-kegiatan berikut, diantaranya :

Adanya pembelajaran yang di integrasikan, maka di Sekolah Dasar Alam tidak ada mata pelajaran khusus PAI. Pembelajaran PAI kontekstual terlihat pada awal pembelajaran IPA terdapat peserta didik yang menanyakan mengapa harus tema kayu yang dibahas. Kemudian fasilitator mengaitkan Asmaul Husna dengan lingkungan di sekitar sekolah bahwa Allah Swt mempunyai sifat Ar-Rahman yaitu maha pengasih lagi maha penyayang dengan memberikan manfaat kayu untuk kehidupan manusia dan Al-Mubaimin yaitu Maha memelihara. Selain itu pembelajaran PAI kontekstual terlihat ketika fasilitator memberikan hadits tentang marah setelah terjadinya perkelahian antar peserta didik. Hal tersebut merupakan upaya untuk mengkontekskan hadits dengan kejadian yang dialami peserta didik.

\section{Memanfaatkan Alam}

Lingkungan alam di sekitar sekolah dapat menjadi salah satu sumber belajar yang diambil manfaatnya sekaligus dijadikan tempat bereksplorasi. Asmaul Husna di kaitkan dengan lingkungan di sekitar sekolah bahwa Allah Swt mempunyai sifat $A r$-Rahman yaitu maha pengasih lagi maha penyayang dengan memberikan manfaat kayu untuk kehidupan manusia dan $A l-$ Mubaimin yaitu Maha memelihara. Manusia juga diperintah untuk menjaga lingkungan sekitar. Fasilitator mengajak peserta didik untuk mengamati berbagai fenomena yang terjadi di area sekolah kemudian mengaitkannya dengan materi pelajaran. Seperti adanya orang yang tenggelam di sungai Bengawan Solo. Materi yang disampaikan mengenai rukun iman yang ke enam yaitu keyakinan pada qada dan qodarnya Allah, bahwa kematian memang sudah ditetapkan tetapi sebagai manusia tidak boleh langsung pasrah, melainkan diajurkan berikhtiar semaksimal mungkin untuk menjaga diri dari musibah. PAI yang ada di sekolah dasar Alam mengajarkan dalam berkehidupan perlu adanya keseimbangan yang berkaitan meliputi hubungan antara manusia dengan pencipta, hubungan antar ssesama manusia, dan bagaimana hubungan manusia dengan lingkungan alam. Antara iman, islam, dan ihsan dapat terealisasi.

\section{Keteladanan dan Pembiasaan}

Akhlak memiliki posisi yang tinggi dalam Islam, sehingga setiap aspek dari pembelajaran selalu diorientasikan pada pembetukan akhlak yang mulia. Untuk mencapai hasil yang diinginkan, Sekolah Dasar Alam biasanya menerapkan keteladanan dan pembiasaan melalui aktivitas seharihari peserta didik, seperti; akhlak terhadap fasilitator, akhlak kepada teman, akhlak ketika makan, akhlak terhadap tumbuhan, akhlak terhadap diri sendiri, dan lain sebagainya. Seperti yang terlihat saat jam makan siang anak-anak diajarkan untuk mandiri mengambil nasi, lauk sendiri, serta setelah selesai makan mereka juga mencuci piring sendiri. Mereka juga membudayakan mengantri saat mengambil makanan, makan dengan duduk dan dipimpin salah satu untuk berdoa.Terdapat kantin kejujuran, peserta didik dapat membeli makanan di kantin tersebut dengan menaruh uang pada tempat yang disediakan.

Pembelajaran kontekstual di sekolah alam memberi peserta didik lebih banyak kesempatan untuk melakukan, mencoba dan mengalami sendiri. Mengajar tidak hanya sekedar transfer ilmu, tetapi juga memfasilitasi peserta didik memiliki pengetahuan dan keterampilan yang dipelajari. Dengan cara ini, belajar terasa lebih bermakna. Ilmu yang dipelajari di sekolah akan dikaitkan dengan situasi dan permasalahan hidup dalam keluarga dan masyarakat. Hal ini juga didasarkan pada landasan kontekstual yaitu filsfat konstruktivisme, pembelajaran bukan sekadar mengingat teori-teori, tetapi proses mengkonstruksi pengetahuan melalui berbagai pengalaman.

Setiap hari peserta didik membiasakan diri untuk shalat dhuha. Aktivitas ini dilakukan sebelum dilakukan proses pembelajaran. Peserta didik melakukan shalat dhuha mandiri dan pada hari tertentu shalat dhuha secara berjamaah. Kegiatan tersebut berguna untuk evaluasi shalat mereka baik gerakan maupun bacaannya serta adab saat berada di Masjid. Peserta didik diajarkan untuk berinteraksi dengan warga, adanya kegiatan shalat dhuhur dan shalat Jumat yang dilakukan 
di Masjid Kampung. Shalat dhuhur yang di jalankan 4 hari di masjid warga dan 1 hari di Sekolah untuk membetulkan gerakan, bacaan shalat peserta didik. Dalam berqurban peserta didik diminta untuk mengumpulkan iuran yang nantinya akan dibelikan hewan qurban. Latihan qurban ini dilaksanakan di Sekolahan bersama dengan orang tua. Mereka juga dimintai tolong untuk membagi-bagikan daging kepada masyarakat.

Pada hari tertentu sebelum pembelajaran dimulai, diisi dulu dengan materi literasi bercerita berupa kisah Nabi dan sahabat, cerita inspriratif lain yang bisa diambil keteladanannya. Pada kesempatan ini bercerita mengenai "Pengemis Yahudi Buta". Penyampain materi tidak hanya bercerita, melainkan peserta didik diajak untuk menceritakan pengalaman mereka bertemu dengan pengemis. Peserta didik diberikan tugas untuk bersedeqah kepada yang tidak membutuhkan. Melalui kegiatan bersedeqah ini peserta didik belajar berbagi dengan sesama, bersyukur atas apa yang dimiliki, dan mereka dapat meneladani sikap Rasulullah. Kegiatan ini menumbuhkan kesan yang nyata, bahwa pembelajaran tidak hanya sekedar teori. Peserta didik juga akan terasah mengenai pengetahuan, sikap emosional, dan hati mereka. Harapannya pembelajaran akan lebih bermakna dengan adanya interaksi bersama warga. Apa yang dipelajari akan dikaitkan dengan situasi, kondisi dan permasalahan hidup dalam keluarga ataupun lingkungan sosial.

\section{Mengaitkan dengan Budaya Lokal}

Pembelajaran PAI kontesktual di sekolah dasar alam juga dapat dikaitkan dengan budaya dan kebiasaan masyarakat setempat, salah satunya tema kayu dapat dihubungkan dengan kondisi masyarakat sekitar sekolah alam. Tujuan dari adanya mengaitkan dengan budaya dan kebiasaan masyarakat di sekitar Sekolah, tentu supaya peserta didik lebih memahami tentang pemanfaatan kayu untuk kehidupan manusia yang dapat bernilai jual, menumbuhkan jiwa wirausaha, menghargai aneka profesi dan manfaatnya. Dengan adanya bisnis meubel peserta didik diajak untuk membahas terkait materi muamalah yaitu halal atau haram dalam kehidupan sekitar yang mayoritas bisnisnya di perkayuan. Melalui beberapa kegiatan di atas mereka diajarkan untuk hidup berdampingan dengan masyarakat. Memanfaatkan alam menjadi sumber belajar dapat dikatakan bahwa sekolah dasar alam Bengawan Solo mengaitkan pembelajaran dengan kearifan lokal.

\section{PEMBAHASAN}

Pembelajaran kontekstual merupakan proses pembelajaran yang bertujuan untuk membantu siswa memahami modul akademik yang mereka pelajari dengan menghubungkan tema akademik dengan lingkungan dalam kehidupan sehari-hari. termasuk lingkungan kondisi pribadi, sosial dan budaya. Dengan menghubungkan 8 komponen berikut: membuat keterkaitan yang bermakna, melaksanakan pekerjaan yang bermakna, melaksanakan pembelajaran mandiri, berkolaborasi, berpikir kritis dan kreatif, membantu pertumbuhan dan perkembangan siswa, mencapai standar tinggi, dan menggunakan penilaian otentik (B.Johnson, 2014).

Pembelajaran situasional merupakan metode pembelajaran yang menghubungkan modul pembelajaran dengan kehidupan nyata siswa di rumah, sekolah dan masyarakat, dengan tujuan untuk menemukan pentingnya materi yang dipelajari dalam kehidupan mereka (Komalasari, 2014). Dalam perihal ini pembelajaran kontekstual berupaya menghadirkan kondisi nyata agar siswa dapat menghubungan antara materi yang dipelajari dengan kehidupan sehari-hari. Guru / Fasilitator membantu siswa menghubungkan materi yang diajarkan dengan dunia nyata dan mendorong siswa untuk menghubungkan pengetahuannya dengan kehidupan di masyarakat.

Landasan utama pembelajaran kreatif, aktif, inovatif, efektif dan menarik adalah konstruktivisme. Menurut Cobern dalam Suprijono (2015) kontruktivisme bersifat kontekstual. Adapun menurut Sanjaya (2009) kontekstual dipengaruhi oleh filosofi konstruktivisme yang digagas oleh Mark Baldwin dan dikembangkan oleh Jean Piaget. Filsafat konstruktivisme tentang hakikat pengetahuan mempengaruhi konsep proses pembelajaran. Belajar tidak hanya mengingat, tetapi juga proses membangun pengetahuan melalui pengalaman. Menurut Piaget sejak masa kanak-kanak, setiap anak memiliki struktur kognitif yang disebut "skema", yaitu pengalaman. Dari 
pendapat di atas memiliki keselarasan mengenai landasan filosofis kontekstual, sehingga dapat di simpulkan bahwa pembelajaran kontekstual secara filosofisnya mengacu filsafat kontruktivesme Mark Baldwin dan dikembangkan Jean Piaget.

Kontekstual dapat diterapkan dengan memperhatikan berbagai komponen-komponen utamanya. Ada tujuh komponen kontekstual menurut Suprijono (2015) yaitu: 1) kontruktivisme adalah strategi mengajar yang didasarkan pada keyakinan bahwa siswa belajar terbaik jika mendapatkan pengetahuan melalui kegiatan pembelajaran aktif dan eksplorasi . 2) Inkuiri adalah proses berfikir kritis, cara ini dapat diperoleh dengan mengamati, mengajukan pertanyaan, mengajukan berbagai hipotesis, mengumpulkan data dan akhirnya menarik kesimpulan. Berbagi bentuk penyajian dari inkuiri dapat berupa gambar, tulisan, tabel, laporan, bagan, karya lainnya. Hasil tersebut selanjutnya dikomunikasikan kepada teman sekelas, guru, pembaca, atau audience lainnya (Syaiful Sagala, 2017). 3) bertanya digunakan untuk membangun dialog interaktif melalui tanya jawab melalui semua elemen yang terlibat dalam komunitas belajar. Kegiatan ini sangat penting untuk mengumpulkan informasi, mengkonfirmasi informasi yang diketahui, dan mengarahkan perhatian ke informasi yang tidak diketahui. 4) masyarakat belajar digunakan untuk menekankan pentingnya belajar sebagai proses sosial. Dengan berinteraksi dalam komunitas belajar, proses dan hasil belajar menjadi lebih bermakna. Konsep masyarakat belajar ialah hasil belajar dapat diperoleh dari kolaborasi dengan orang lain. 5) Modeling, dimana siswa dapat meniru apa yang mereka lihat. Bentuk model dapat berupa cara mengoprasikan hal-hal tertentu, contoh karya tulis, pelafalan bahasa ataupun yang lainnya. 6) refleksi merupakan bagian penting dari pembelajaran kontekstual. Refleksi adalah upaya untuk memeriksa kembali, mengatur kembali, menganalisis kembali, memperjelas dan mengevaluasi kembali apa yang telah dipelajari. Dalam proses refleksi, guru biasanya merangkum hasil belajar; 7) penilaian sebenarnya adalah mengumpulkan berbagai data, yang dapat merangkum perkembangan belajar siswa. Data tersebut berasal dari kegiatan nyata yang dilakukan siswa selama proses pembelajaran, sehingga laporan kepada orang tua tidak hanya berupa raport, tetapi juga meliputi hasil karya siswa, laporan praktikum, dan karangan siswa.

PAI kontekstual di Sekolah Dasar Alam dilakukan dengan memasukkan nilai-nilai agama dalam aktivitas peserta didik di dalam kelas atau diluar kelas, mereka diajak untuk mentadaburi dan mengambil ibroh dari setiap kejadian, mengaitkan PAI dengan materi pembelajaran lainnya, karena PAI sangat erat kaitannya dengan kehidupan peserta didik sehari-hari. Hal tersebut singkron jika disandingkan dengan pernyataan dari Kulsum et al., (2016) mengintegrasikan berbagai pembelajaran internal maupun eksternal dapat menjadikan pembelajaran lebih luwes dan bermakna karena dekat dengan kehidupan sehari-hari. Peserta didik akan menghadapi permasalahan konkrit, kemudian berdiskusi dan mempraktikkan.

Sedangkan menurut Fa'atin (2017) bahwa pendekatan integratif dalam pembelajaran alQur'an dapat mengoptimalisasi pemahaman siswa dan memberikan pengalaman nyata dalam menerapkan al-Qur'an dan Hadits dalam lingkungan masyarakat sekitar. Menerapkan pembelajaran integrasi sunnah kauniyah di alam sekitar dengan kehidupan sosial-masyarakat melalui ajaran Islam dapat mewujudkan proses pembentukan manusia menjadi khalifah di bumi (Abdulloh Hadziq, 2016). Penelitian dari Siregar et al., (2020) ayat, hadits dan tafsirnya diintegrasikan pada setiap proses pembelajaran yang dapat memberikan pemahaman bahwa Islam adalah sumber ilmu-ilmu rasional dan sumber nilai. Hal tersebut berdampak pada peningkatan ketrampilan berfikir kreatif, inovatif, motivasi belajar dan kritis peserta didik, selain itu mereka juga akan mempraktekkan pengetahuan yang diperoleh dalam bentuk sikap dan perilaku dalam bertindak.

Pemanfaatan alam juga hadir dalam setiap pembelajaran, hal ini sesuai dengan ungkapan Daradjat (2001) yang menyatakan bahwa Pendidikan Agama Islam memiliki tiga ruang lingkup yaitu: keseimbangan hubungan sosial antar manusia baik itu kewajiban maupun larangan terhadap sesama. Hubungan manusia dan alam sebagai khalifah di muka bumi, memiliki misi melindungi dan memanfaatkan dengan baik semua yang telah Allah berikan. 
Jenis pembelajaran kontekstual salah satunya adalah memanfaatkan alam untuk memperoleh pengalaman belajar selain itu begitu peserta didik sangat terbantu terbantu dalam memahami materi yang biasanya hanya disampaikan melalui buku teks atau kata saja. Hal tersebut sesuai dengan pendapat Majid (2012) serta hasil penelitiannya Abdullah Hadziq (2018) dan Baen (2019) yang mengungkapkan bahwa kebun atau sawah yang nyata dapat dijadikan sumber belajar yang menarik bagi anak, alam bisa menjadi laboratorium dan bagian dari proses belajar mengajar. Melalui alam mereka juga dapat menumbuhkan nilai-nilai keimanan sebagaimana yang diungkapkan (Gunawan \& Rahmah, 2019) bahwa, mengajak siswa untuk mengamati apa yang terjadi di area lingkungan kemudian dikaitkan dengan materi pelajaran yang dibahas, hal tersebut menumbuhkan internalisasi nilai-nilai religius dan dapat menumbuhkan motivasi dan melaksanakan ajaran agama.

Keteladanan dan pembiasaan merupakan pembelajaran yang efektif dalam kontektualisasi pembelajaran. Dengan dibiasakan berperilaku sesuai dengan akhlak mulia, secara tidak langsung peserta didik ikut terlibat didalamnya dan pembelajaran akan lebih bermakna. Setiap anak memiliki potensi dan fitrahnya masing-masing, maka hal tersebut perlu diarahkan dengan anak dibiasakan berbuat baik. Hasil penelitian ini mendukung penelitian dari Kulsum et al., (2016) bahwa internalisasi nilai-nilai akhlak salah satunya menggunakan multi metode yaitu pembelajarannya tematik, adanya peneladanan, pembiasaan, pemberian motivasi, penegakan berbagai aturan. Akhlak yang baik akan menjadikan sebuah karakter, karakter seseorang akan muncul ketika dibiasakan dilakukan berulang-ulang dalam jangka yang lama, serta perlu dukungan dari lingkungan sekitar (Choiriyah, 2016). Hal tersebut didukung oleh Budianto (2010) bahwa pembentukan karakter dapat dilakukan melalui pembelajaran pendidikan agama Islam berbasis kontekstual. Senada dengan Abdi (2011) bahwa pembelajaran CTL akan lebih menyentuh afeksi peserta didik serta mampu memotivasi untuk dapat mengaktualisasikan nilai-nilai yang telah didapatkan dari pembelajaran. Sedangkan menurut Kulsum, Husaini, and Saefuddin (2016) untuk mendukung Internalisasi nilai-nilai akhlak dalam pembelajaran Tematik perlu diterapkan metode pembiasaan, peneladanan, penegakan aturan dan pemberian motivasi. Penanaman nilai-nilai keagamaan dapat dilakukan dengan mengembangkan budaya religius oleh warga sekolah melalui kegiatan pembiasaan, keteladanan, maupun pendekatan persuasif (Nurhidin, 2017).

Mengutaman peraktik dan pengalaman bagi peserta didik dalam pembelajaran menjadi keniscayaan dalam pendidikan agama Islam, sehingga ilmu yang didapatkan di sekolah harus diperaktikkan dalam kehidupan sehari-hari. Sekolah Alam menyadari bahwa Pendidikan agama Islam sangat penting bagi kelangsungan hidup peserta didik. Sehingga aktivitas pembelajaran diarahkan untuk mengenalkan PAI di berbagai sendi kehidupan melalui praktik langsung. Senada dengan Kadir (2013) pembelajaran kontekstual dapat menjadi alternatif pembelajaran yang meminimalisir adanya teoritis dan verbalisme serta pembelajaran ini mampu menguatkan secara komperhensif dari apa yang dipelajari dengan pengalaman langsung. Pembelajaran dengan metode praktik dan pengalaman menurut Titin (2016) dan Choiriyah (2016) dapat meningkatkan hasil belajar PAI.

Sekolah sebagai identitas sekolah tentunya mempunyai budaya lokal yang khas, sehingga hal tersebut perlu terintegrasi dalam proses pembelajaran. Konsep mengaitkan pembelajaran PAI kontekstual dengan kearifan lokal betujuan menciptakan suatu manfaat tersendiri bagi peserta didik akan kekayaan dan potensi lokal daerah. Mampu menumbuhkan kreatifitas, jiwa wirausaha, dan lebih peka akan potensi yang dimiliki di daerah tempat tinggal masing-masing. Penelitian tersebut di dukung oleh Utari et al., (2016) bahwa nilai-nilai kearifan lokal membantu peserta didik dalam memahami konsep materi, hal tersebut menjadikan pengetahuan tidak hanya sebatas pengetahuan saja, tetapi dapat diimplementasikan dalam wujud praktek di luar kelas. Senada dengan hasil penelitian Mawardi (2012) bahwa Pembelajaran dengan menggunakan kearifan lokal memberikan nilai tambah pada pengembangan kecakapan hidup para peserta didik, kecakapan tersebut akan membangun karakternya dan memunculkan sikap kreatif, bertanggung jawab, dan 
mandiri. Penanaman potensi lokal dapat dilakukan melalui integrasi dengan pembelajaran tematik (Nafia Wafiqni, 2018).

Seperti halnya penelitian dari Rochanah (2018) bahwa di sekolah dasar dapat memadukan kurikulum kearifan lokal melalui integrasi antara pendidikan formal dan non formal. Hal tersebut dilakukan agar santri yang belum bisa menjadi bisa, dari belum mengetahui menjadi mengerti, dan yang sudah bias menjadi lebih bisa. Adanya keterkaitan antara tradisi dan budaya masyarakat dengan Agama Islam yang dijadikan sebagai alat untuk mendekatkan Islam dengan masyarakat. Mengaitkan dengan budaya lokal dapat dilakukan dengan cara menyusun rencana pelaksanaan pembelajaran (RPP) yang berbasis kearifan lokal dalam pembelajaran PAI (Ramadhan \&Dendy, 2019).

Hasil pembelajaran kontekstual dapat dirasakan oleh fasilitator dan orang tua. Peserta didik lebih mudah dalam memahami materi, terbiasa berdiskusi dalam memecahkan permasalahan. Fasilitator juga sering mendapatkan laporan dari orang tua mengenai hasil aplikasi pada kegiatan sehari-hari. Hal tersebut mendukung Suyadi (2013) dan Saputra (2014) yang menyatakan bahwa pembelajaran kontekstual mendorong siswa untuk menangkap materi yang berkaitan dengan kehidupan nyata, pengembangan prestasi siswa dalam memahami, mengamalkan ajaran agama Islam, berfikir kritis, minat belajar yang tinggi, menghubungkan AlQur'an dengan kehidupan untuk dijadikan inspirasi, dan dapat meningkatkan kemampuan guru PAI dalam melaksanakan proses pembelajaran.

PAI tidak hanya bersifat pragmatis saja melainkan bersifat normatif. Pencapain pembelajaran PAI tidak hanya diukur dari hasil tes atau angka diraport. Melainkan, juga dilihat dari sejauhmana pengetahuan, sikap, dan perilakunya diterapkan dalam kehidupan sehari-hari. Sekolah ini juga menerapkan penilaian dengan melakukan pengamatan dan evaluasi perilaku keseharian siswa, sehingga penilaian diarahkan berdasarkan proses belajar bukan hanya berorientasi pada hasil semata. Akan dihasilkan dua raport yaitu dalam bentuk deskriptif dan angka. Hal ini sesuai dengan ungkapan Majid (2013) yang menyatakan bahwa karakteristik dalam pembelajaran kontekstual yaitu laporan kepada orang tua tidak hanya rapor, tetapi juga berupa hasil karya siswa, karangan siswa dan laporan praktikum.

Pembelajaran Pendidikan Agama Islam kontektual didukung oleh berbagai kegiatan sekolah baik yang terprogram seperti: outbond, outing class,berkebun, shalat dhuha sebelum pembelajaran, shalat berjamaah di Masjid kampung bersama dengan masyarakat, kegiatan sosial seperti berqurban dan sedekah. Merekapun dibiasakan dalam menerapkan adab dan akhlak yang baik pada kegiatan aktivitas yang dilakukan oleh peserta didik seperti berteman, ketika makan, ketika berbicara kepada yang lebih tua, sehingga pembelajaran PAI menyentuh berbagai hal baik kognitif, afektif maupun psikomotorik

\section{KESIMPULAN}

Pendidikan Agama Islam kontekstual di Sekolah Dasar Alam dilakukan melaui: integrasi dengan seluruh mata pelajaran, mengutamakan praktik dan pengalaman, keteladanan dan pembiasaan dan mengaitkan dengan budaya lokal. Pembelajaran didukung dengan kegiatan sebagai berikut: outbond, outing, berkebun, shalat dhuha sebelum pembelajaran, shalat berjamaah di Masjid kampung bersama dengan masyarakat, kegiatan sosial seperti berqurban dan sedeqah, menerapkan adab dan akhlak yang baik pada kegiatan aktivitas yang dilakukan oleh peserta didik seperti berteman, ketika makan, ketika berbicara kepada yang lebih tua. Pembelajaran PAI kontekstual dapat mempermudah siswa dalam memahami materi yang abstrak, selain itu fasilitator mendapat laporan dari orang tua peserta didik bahwa apa yang mereka pelajari di Sekolah diimplementasikan ketika berada di rumah. Pembelajaran kontekstual menekankan pentingnya sebuah proses sejauhmana pengetahuan, sikap, dan perilaku dapat diterapkan peserta didik dalam menjalani berbagai aktifitas dalam berkehidupan, tidak hanya pada hasil belajar. 


\section{UCAPAN TERIMAKASIH}

Kami ucapkan terimakasih kepada berbagai pihak atas kerjasamanya dalam penelitian ini, lebih khusus kami sampaikan kepada Sekolah Dasar Alam Bengawan Solo yang telah memberikan izin pada tim peneliti.

\section{REFERENSI}

Abdi, M. I. (2011). Contekstual Teaching and Learning dalam Pembelajaran PAI.

BJohnson, E. (2014). CTL Contextual Teaching and Learning (I. Setiawan (ed.); 1st ed.). Kaifa.

Baen, F. (2019). Efektifitas Media Alam Dalam Pembelajaran Pendidikan Agama Islam (Pai) Di

Sekolah Alam Ungaran (Saung) Kabupaten Semarang

Baen, F Jumal Studi Dan Penelitian Pendidikan Islam, 2, 91-101.

Budianto, E. (2010). Pendidikan Karakter Melalui Pembelajaran PAI Berbasis Kontekstual. 89.

Choir, A. (2019). Pembelajaran Pendidikan Agama Islam (Pai) Berbasis Aktivitas Kontekstual Di

Mi Alam Alfa Kids Pati. Quality, 7(1), 114-131. https://doi.org/10.21043/quality.v7i1.5226

Choiriyah, A. (2016). Model Pembelajaran Pengalaman Langsung Pendidikan Agama Islam Dan.

Nur El-Islam, 3(2), 48-82

Daradjat, Z. (2001). Islam, Pengajaran Agama. PT Bumi Aksara.

Fa'atin, S. (2017). Pembelajaran qur'an hadits di madrasab ibtidaiyah dengan pendekatan integratif multidisipliner.

Gunawan, Z., \& Rahmah, A. (2019). Contextual Teaching And Learning Approaches And Its Application In Pai Learning In. 06(02), 557-592.

Hadziq, A. (2018). Pendidikan Anti Kekerasan Berwawasan Lingkungan. At-Tarbawi: Jurnal Kajian Kependidikan Islam, 3(1), 55. https:// doi.org/10.22515/attarbawi.v3i1.1309

Hadziq, A. (2016). Pembelajaran Agama Dan Lingkungan Dalam Kultur Sekolah Alam: Potensi Membumikan Kesadaran Lingkungan Sejak Dini Di Sekolah. Jurnal Tatsqif, 14(1), 1-32. https://doi.org/10.20414/jtq.v14i1.19

Hartono. (2013). Konsep Belajar dan Pembelajaran Menurut QS. An-Nabl: 78. 16(40), 311-326. http:/ / www.ghbook.ir/index.php?name= مجمو عه مقالات دومين هم انديثى سر اسرى رسانه تلويزيون 9

سكو لاريسم \&option=com_dbook\&task=readonline\&book_id=13629\&page=108\&chkhashk $=03 \mathrm{C} 706812 \mathrm{~F} \&$ Itemid $=218 \&$ lang $=$ fa\&tmpl $=$ component

Ilyas, A., Effendi, Z. M., Gistituati, N., \& Anand, A. (2018). Pengembangan Model Pembeljaran Inkuiri Dalam Mata Pelajaran Agama Islam (Pai) Di Sekolah Dasar. Proceeding IAIN Batusangkar, 1(2), 45-60.

Indonesia, D. A. R. (2012). Al-Quran dan Terjemahannya. CV Darus Sunnah.

Abdul. K (2013). Konsep Pembelajaran Kontekstual Di Sekolah. Dinamika Ilmu, 13(1), 17-38. http://journal.iain-samarinda.ac.id/index.php/dinamika_ilmu/article/view/20

Komalasari, K. (2014). Pembelajaran Kontekstual Konsep dan Aplikasi (4th ed.). PT Refika Aditama.

Kulsum, R. U., Husaini, A., \& Saefuddin, D. (2016). Internalisasi Nilai-Nilai Akhlak Melalui Pembelajaran Tematik pada Sekolah Dasar Sekolah Alam Bogor. Ta'dibuna: Jurnal Pendidikan Islam, 5(2), 184. https://doi.org/10.32832/tadibuna.v5i2.590

Majid, A. (2012). Belajar dan Pembelajaran Pendidikan Agama Islam (1st ed.). PT Remaja Rosdakarya. Majid, A. (2013). Strategi Pembelajaran. PT Remaja Rosdakarya.

Mawardi, I. (2012). Pendidikan Life Skills Berbasis Budaya Nilai-nilai Islami dalam Pembelajaran. 
Nadwa, 6(2), 215. https://doi.org/10.21580/nw.2012.6.2.589

Minarti, S. (2013). Ilmu Pendidikan Islam: Fakta Teoritis-Filosofis dan Aplikasi Normatif. AMZAH.

Muhaimin. (2002). Paradigma Pendidikan Islam. PT Remaja Rosdakarya.

Muslimin. (2017). Problematika Pembelajaran Pendidikan Agama Islam dan Upaya Solusi Guru Agama dalam Pembinaannya di Sekolah. Tarbawiyah: Jurnal Ilmiah Pendidikan, 01(2), 2. file://C:/Users/Tantan Heryadi/Downloads/1018-49-2668-1-10-20180107.pdf

Wafiqni, N S. N. (2018). Model Pembelajaran Tematik. Al Bidayah: Jurnal Pendidikan Dasar Islamah, 10(2), 255-270.

Nurhidin, E. (2017). Inovasi Pembelajaran Pendidikan Agama Islam (PAI) Melalui Pemanfaatan Media Pembelajaran Kontekstual Dan Pengembangan Budaya Religius Di Sekolah. Kuttab, 1(1), 1-14. https://doi.org/10.30736/kuttab.v1i1.95

Ramadhan dan Dendy. (2019). Relevansi Kearifan Lokal Tepung Tawar Dalam Pembelajaran Agama Islam (Studi Pada Masyarakat Melayu Pontianak). 8(1), 53-62.

Rochanah. (2018). Lingkungan Alam Sebagai Media Kekuasaan Allah Pada Anak Usia. Jurnal Elementary, 6(1), 107.

Rohmadi, S. H. (2012). Pengembangan Kurikulum Pendidikan Agama Islam. Araska.

Rouf, A. (2015). Potret Pendidikan Agama Islam Di Sekolah Umum Abd. Rouf (Guru SMPN 41 Surabaya). Jurnal Pendidikan Agama Islam UIN Sunan Ampel, 03(No. 1 (2015)), 187-206. https://doi.org/DOI: http://dx.doi.org/10.15642/jpai.2015.3.1.187-206

Sanjaya, W. (2009). Strategi Pembelajaran Berorientasi Standar Proses Pendidikan (6th ed.). Kencana Prenada Media Group.

Saputra, A. (2014). Aplikasi Metode Contextual Teaching Learning (CTL) Dalam Pembelajaran PAI. At - Ta'Dib, Volume V,(Pendidikan Agama Islam), 1-124.

Siregar, M., Zahra, D. N., \& Bujuri, D. A. (2020). Integrasi Materi Pendidikan Agama Islam Dalam Ilmu-Ilmu Rasional Di Sekolah Menengah Atas Islam Terpadu. Al-Tadrkiyyah: Jurnal Pendidikan Islam, 10(2), 183-201. https://doi.org/10.24042/atjpi.v10i2.4847

Suarjana, J. I. G. N. dan I. M. (2015). Buku Ajar Pendidikan Matematika I. Udisksha Press.

Suprijono, A. (2015). Cooperative Learning Teori dan Aplikasi P AIKEM (14th ed.). Pustaka Pelajar.

Suyadi. (2013). Strategi Pembelajaran Pendidikan Karakter. PT Remaja Rosdakarya.

Sagala, S. (13th ed.). (2017). Alfabeta.

Tamam, M. B. (2015). Patroman, Model Pembelajaran Kontekstual Pada Mata Pelajaran PAI Di SMP Al-Ažbar Banjar. III(2), 40-45.

Titin, S. (2016). Pengaruh Metode Pembelajaran Praktik Terhadap Motivasi Dan Hasil Belajar Pendidikan Agama Islam Siswa Kelas IV Sekolah Dasar. Studia Didkatika Jurnal Ilmiah Pendidikan, 10(2), 1-18.

Utari, U., Degeng, I. N. S., \& Akbar, S. (2016). Pembelajaran Tematik Berbasis Kearifan Lokal Di Sekolah Dasar Dalam Menghadapi Masyarakat Ekonomi Asean (MEA). Jurnal Teori Dan Praksis Pembelajaran IPS, 1(1), 39-44. https://doi.org/10.17977/um022v1i12016p039 